\title{
磯貝 豊（東京電力病院耳鼻咽喉科）
}

われわれは, 竹内の剧案した $\mathrm{ABC}$ 法 ${ }^{1}$ を基に, $\mathrm{ABC}$ 法に「気導音の両耳間移行減衰量 (IA) は伝音損失量 $(C L)$ 以上大」あるいは「伝音損失量 $(C L)$ は気導音の両耳間移行 減衰量（IA）を越えない」とするIA 法則を導入したマスキング理論と方法をあらたに $\mathrm{ABCI}$ 法 $^{2) \sim 6)}$ として考案し，昨年度の本学会では，ABCI法の立場からみた骨導雑音法 について報告?゙た。

A BCI 法は，IA 法則から想定されるすべてのケースの聴力像（6通り）をもとに，そ の鑑別法としてのマスキング法，すなわち，シャドウヒアリング(以下， SH）とオーバー マスキング(以下，OM）の効率的な検定法を理論的に構築したものである。

一方，もっともポピニラーなプラト一法は，IA 法則を導入していないため，マスキン グ側（以下， $M$ 側）のマスキング・ノイズ・レベル（以下 $M$ ）を徐々に上昇させていった時， 最初にブラトーを生じたレベルが真の域値，次にプラトーが消失したレベルがOMレベル であるという，試行錯照的かつ経験則的な域を出ないマスキング理論と方法である。

今回は, A BCI 法の立場からみたプラト一法について報告する。

1. 気導域値が SHされた域値の場合の気導域値のプラトー（図 $1 \& 2) 。$

この場合の聴力像は，IA 法則から，図1の関係が成立する。すなわち，

(1) SHされた気導域値 $x=$ [前額正中骨導域値 BC (口)+IA], (2) 非 SH側骨導域値 $[=$ 前額正中骨導域値 $\square$, (3) SH 側骨導域値真値 $] \geqq]=(\square+$ 気導域值のSH分 $)=\square+$ [気導域值真值 $\otimes-\mathrm{SH}$ された気導域値 $\times$ ，，(4)両耳の骨導マスキングレベル差 $=M$ 側の 骨導マスキング・ノイズ・レベル（以下，BM）一反対側 $B M=[\square+(M-M$ 側気導域値 O) $]-[M-I A]=[0+I A]-O=x-O か ゙$ 常に成立する。

したがって，Mを○のレベルから上昇させていくと，気導域值は最初，気導域值の S H 分 $=($ 冈ーメ)だけ上昇するが，以後はプラトーに達し，M側の $B M=S$ H 側骨導域值真 値]になるレベルから，さらに，両耳の骨導マスキングレベル差分 $=[\square+I A]-O=$ (メー○)分だけMを上昇させてもOMにはならない。

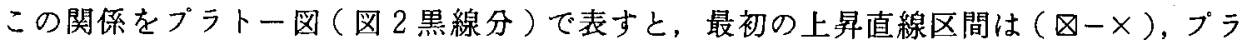

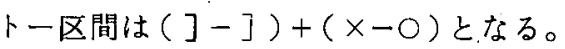

2. 気導域值が SHされた域值の場合の骨導域値のプラト一(図 2 白抜き線分)。

この場合は，図2のM側の BMが]に達するまではM側 BMで SHされるので，プラト一 分は $(x-O)$ 分になる (図 2 中点線部分)。

3. 気導域値にSHがない場合の気導域値のブラトーについて（図３）。

この場合は，M側骨導域值の如何にかかわらず，M側の反対側（検查側）の $B M=(M-$ I A ）が検查㑡骨導域值了のレベルに達するまではOMにならずにブラトーが生じる。 ]$=\square$ 場合は，検查側 BMが口になるのは $\mathrm{M}=(\square+\mathrm{I} A)$ のレベルなので，実効レベル $(\mathrm{M}-\mathrm{O})$ で表すと [( 一口）分 $\mathrm{M}$ を上算させても OMにはならないので，プラトー区間が延長する。

4.気導域値にS Hがない場合の骨導域値のプラトーについて（図 4 )。 


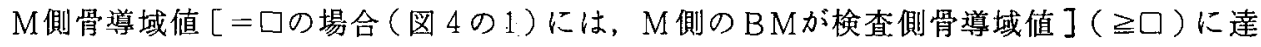
するまで，すなわち，実効レベルで(]ー口)分だけ骨導域值は上昇するが，以降は，両耳 の $\mathrm{BM}$ 差分 $=\mathrm{M}$ 側 $\mathrm{BM}$ 一検查側 $\mathrm{BM}=[\square+(\mathrm{M}-\mathrm{O})]-[\mathrm{M}-\mathrm{IA}]=[(\square+\mathrm{IA}]-0]$ 分 だけプラトーを生じて OMになる。

$M$ 側骨導域値 $[>\square($ 図 4 の 2 ) の場合には, 検查側骨導域值 $]=\square$ となる。検査側 $B M=$

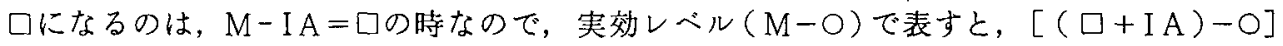
分だけプラトーを生じ，以降はOMになる。

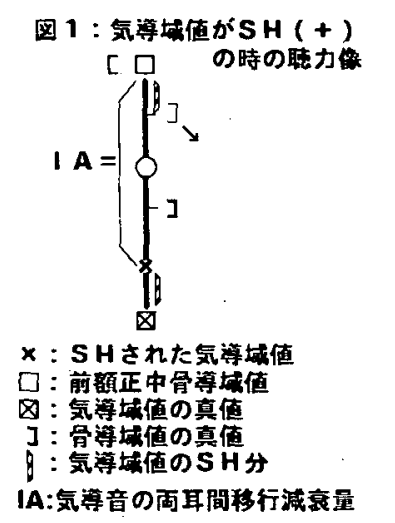

图3:気等城㑲がSH(-)の時の 気泟域值のPlateau
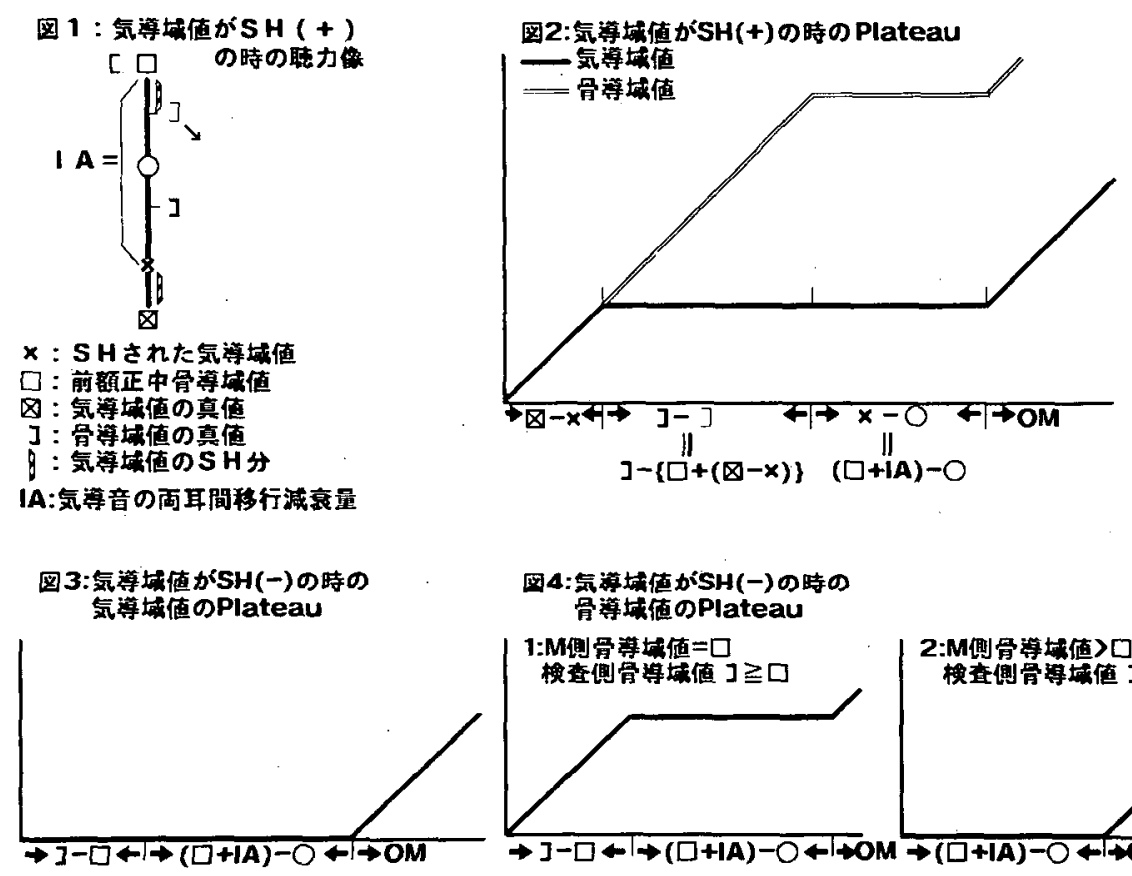

四4:気等域值がSH(-)の時の 骨得城值のPlateau

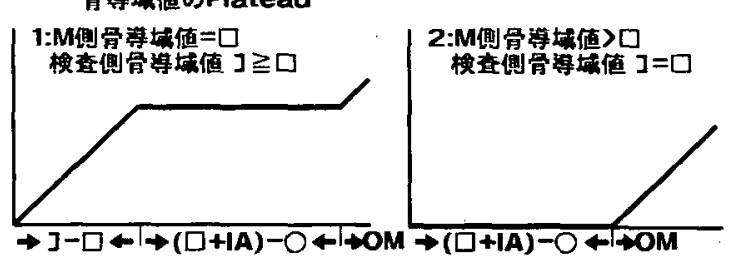

\section{【参考文献】}

1) 竹内義夫；Audiometry Training Simulatorを用いた聴力検查の実習ーマスキング法の理論 と実際一, 物シードル, 1980 ：2) 磯貝 豊; Audiology Japan 28, 519 524, 1985 : 3) 磯貝 豊; 耳展 29,441 453，1986：4）磯貝 豊; Audiology Japan 30, 637 640, $1987: 5$ ) 磯貝 豊; 同 31,475 476, $1988: 6$ ）磯貝 豊; 同 32, 687 688, 1987 : 7) 磯貝 豊; 同 $33,731 \sim 732,1990$ : 